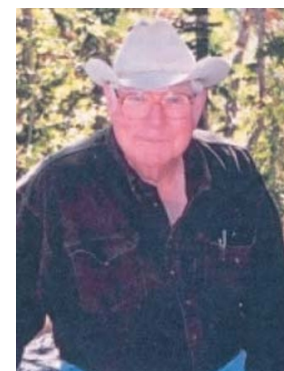

Thad Box

\title{
Professional Choices in a Once and Future World
}

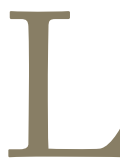

ast November the human population of the world reached seven billion. When I was born (1929) the world had about two billion people. By the time I earned my $\mathrm{PhD}(1959)$ there were three billion. There were 3.7 billion in 1970 when I was appointed dean, and about 5.2 billion when I retired (1990). In the next generation the population will reach eight billion. During my lifetime the world population almost quadrupled. The habitable area decreased. Increasing human density, unequal population distribution, and natural resource values will dictate that land care professionals are destined to work in a conflict zone between haves and have-nots.

Even today, by world standards, I am filthy rich. I live in Utah by choice. About threequarters of my state is public land. The Cache National Forest is about 3 miles east of where I live. Three miles west are wetlands and marshes filled with waterfowl, fish, and aquatic critters of all kinds. In less than an hour I can be in the beauty of cold desert solitude. And I own all these lands-along with about 313 million partners.

Over the decades, I put dozens of mule deer from those lands in my freezer, caught thousands of trout from the streams, and shocked my city-girl wife with fowl of many kinds brought home for her to cook. Meat I shot supplemented steers and lambs I bought from neighbors who grazed livestock on the Cache.

My children and I camped, hiked, and played over land they learned to love and respect. Now they teach their children the importance of stewardship. Jenny and I often worked through good times and bad of our 57-year marriage sitting on a blanket by a mountain stream. When stress of my job got to me, I retreated to those mountains to think and plan. It was no accident that when the terrorist planes hit the world trade towers on 9/11, I hiked to a subalpine cirque to sort out what was really important.

Only the world's rich have such luxury. My grandchildren live in a different world. My riches resulted from our unique system of public land that evolved as our human density increased. After the Revolution, states released their unsettled western lands to the federal government. These public domain lands were to be sold to provide operating funds for a new nation.

During the next 100 years, the United States extended its land holdings to the West Coast through wars, purchase, annexation, and treaties. As our land area increased, we continued to try to sell public lands. In most cases, squatters preceded federal acquisition of land, taking the best land and laying claim to key assets such as springs and ferry sites. During the first half-century after independence, Congress enacted laws aimed at selling public land to individuals and paid soldiers for military service with land warrants.

Then we tried using federal lands to promote development. Grants were made to build wagon roads, canals, and railroads. Land was given to states for infrastructure development. About 86 million acres of the public domain were granted to states for schools and universities. And beginning in 1862, a series of Homestead acts tried to give land to anyone who was willing to live on and develop it. 
Lands with strategic value were sold or given away. The remainder had few takers. Public lands were used, or misused, by anyone who had the resources or audacity to use them by force. The result was millions of acres overused, degraded, and wasting away.

Beginning in the late 19th century, Congress began designating specific areas to be owned in perpetuity by the public: national parks, national forests, national monuments, mineral or fuel reserves, military bases, bombing ranges, etc. With the Taylor Grazing Act of 1934, almost all public land came under federal management. The Federal Land Management and Policy Act of 1976 (FLPMA) declared that federal lands would remain forever in public ownership.

The management of public land is delegated to our hired hands: the Secretary of Interior for parks, the Bureau of Land Management, etc., and the Secretary of Agriculture for the Forest Service. Taxes paid by all of us are used to manage that land. We owners form interest groups to advocate for, or against, specific uses. For decades, some owners worked to remove domestic livestock grazing from the public domain by framing range managers as livestock advocates.

The profession of range management began when scientists applied their knowledge to rehabilitating private lands degraded by overgrazing and the droughts of the late 19th century. It grew as public land agencies were created and sought scientifically trained land specialists for staff positions.

From the beginning, range management was landcentered. But there was a shortage of scientifically trained managers. Early land administrators were political appointees with experience in one of the land's major products: timber, livestock, game, water, etc. They saw the land through the economic value of a commodity. Professional societies such as the Society for Range Management were formed to assure that science, not industries or political ideology, would guide land management toward sustainability.

Some SRM members still see the land through a product. Some think banning livestock grazing from public land will be the death knell of range management. If that is true, we are not a land care profession, but an agent of livestock production. A chapter in an animal husbandry text would suffice.

A profession is supposed to leave the world better for future generations, providing intergenerational transfer of knowledge and opportunities. About a third of the surface area of the United States is public rangeland. Combined with privately owned ranges, almost half our land is rangeland. Public land, held in trust for the people, is not managed for maximizing profit from any given product. Its management objective is to keep options open for future generations, people whose wants and needs cannot be known with certainty.

The Society for Range Management Web site describes it as "a professional scientific society and conservation organization whose members are concerned with studying, conserving, managing, and sustaining the varied resources of the rangelands..."

Millions of the seven billion people now on the earth go to bed hungry each night. The next generation will increase the number of people to over eight billion. Land area per person will decrease. The United Nations estimates that by 2050 the average density on the world's land surface will be about 177 people per square mile. The density of Asia will be about 438 people per square mile and that of North America about 72 .

The lifestyles, values, and need for natural resources of people living under vastly different densities will lead to civil unrest between the haves and the have-nots. We get a hint of what is to come from the strong differences of opinion between the 313 million American public land owners about what they want from their public lands.

Few of our public land users are starving. Most want their grandchildren to have access to the land's bounty. But so do people in Asia and other areas of high population densities and grinding poverty. The have-nots will desperately seek improved opportunity for their children. And professional range managers will need to have an important role in future land use.

Being "concerned" with the "varied resources of rangelands" is not good enough. Our actions must leave the world better than we found it. Aldo Leopold wrote: "a land ethic changes the role of Homo sapiens from conqueror of the land-community to plain member and citizen of it." The extent to which we rededicate our efforts toward the present and future health of the land-community, including its human members, will determine if we are really a profession.

ThadBox,thadbox@comcast.net. 